\title{
The Extent of the Implementation of the Learning Continuity Plan of Panabo City National High School During Covid-19 Pandemic
}

\author{
Theresa R. Baman ${ }^{1}$, Ronald S. Decano ${ }^{2}$ \\ ${ }^{1}$ Graduate Student, Doctor of Philosophy in Educational Management, Davao del Norte State College, Philippines \\ ${ }^{2}$ Dean, Institute of Advanced Studies, Davao del Norte State College, Philippines
}

\begin{abstract}
Covid-19 disease brought threats to humankind worldwide that made the closure of establishments, especially schools, to protect mainly the students, teachers, and its school staff. For this reason, face-to-face sessions were discouraged and other modalities were introduced based on the local Learning Continuity Plan of the school. Panabo City National High School crafted its Learning Continuity Plan based on the Department of Education Order No. 19 series of 2020. This study aims to determine the extent of implementing the Learning Continuity Plan of Panabo City National High School in its learning modalities utilized, the challenges, opinions, and recommendations by the parents, teachers, students, and other stakeholders. The challenges, opinions, and recommendations were identified through a quantitative deductive research design by conducting surveys to the $\mathbf{1 0 0}$ Panabo City National High School participants through quota and purposive sampling. The results showed that the school has implemented its Learning Continuity Plan (LCP) very well and observed by the parents, teacher, students, and other stakeholders and private individuals. The challenges that emerged were limited supply of printing materials in the production and delivery of modules; students struggle with self-studying, parents' lack of knowledge to academically guide their child/children, internet, and other technical capacity issues. In conclusion, the study determined the extent of the implementation of the Learning Continuity Plan and recommendations for any room of improvement. The result of this study may serve as a springboard for the future improvements of the schools' existing programs and guidelines on implementing the Learning Continuity Plan for the next school year.
\end{abstract}

Keywords- students, learning continuity plan, modular distance learning

\section{INTRODUCTION}

$\mathrm{C}$ Corona Virus Disease or commonly called as Covid-19 disease, is undoubtedly a global health issue. This disease posed a significant threat to everyone since it may spread directly or indirectly. Anyone can be a carrier of this virus if not given attention. The virus attacks the respiratory system such as the nose, throat, and lungs. The complication of handling the outbreak, the absence of vaccines and drugs to treat Covid patients has made the government and the Department of Education implement strict policies to break the chain of the spread of Covid-19. Physical distancing or social distancing which limits community interaction, is one way of breaking the chain of spreading Covid-19. However, this physical distancing policy can impede the growth rate in various fields of life, both in the economic, social, and of course education fields. Department of Education (DepEd) ordered an adoption of the Basic Education - Learning Continuity Plan (D.O. 012 s. 2020) as guidance to all offices, units, schools, and community learning centers (CLC's) students and parents, partners, and other stakeholders. In this Learning Continuity Plan, the school must draft a modular learning modality that suits the students' needs in the community.

The availability of a distance learning policy encouraged teachers to conduct online Learning throughout the pandemic. Cellphones are utilized to supply students with topic information and learning tasks. Students learn at home by accessing material given online by the teacher. Students gain from online Learning because it makes the subject matter more accessible to the more straightforwardly and comprehensively. This allows teachers and students to continue teaching and learning even when government rules physically separate them. The efficacy of the learning process may be measured by the instructors' ability to meet specific educational goals. The amount of teacher success in teaching certain groups of students using specific approaches to attain specified instructional goals is the learning process's efficacy. Effectiveness may be measured in instructors' capacity to manage Learning effectively, student participation in Learning, and student learning results. There are two aspects to learning efficacy. The first feature is "making it simple for students to learn" something useful, such as facts, skills, values, concepts, or desired learning outcomes. Second, skills are recognized by those competent to assess, such as teachers, supervisors, tutors, or students themselves (Dunne, as cited in Pujiastutik, 2019).

According to Miarso (as stated in Rohmawati, 2015), learning effectiveness is one of the quality characteristics of education and is usually measured by goal attainment. It can also mean "doing the right thing" or "doing the right thing" in a circumstance. Meanwhile, Supardi (as cited in Rohmawati, 2015) defines effective Learning as a combination of human, material, facilities, equipment, and procedures to change students' behavior in a positive and better direction based on 
their potential and differences to achieve predetermined learning objectives.

\section{METHODOLOGY}

\section{Research Design}

This study will use a quantitative-descriptive research method. It will focus on what is the extent of the implementation of the Learning Continuity Plan of Panabo City National High School that offers modular distance learning to majority of its learners and online distance learning or virtual Learning.

In this method, the extent of implementation of the learning continuity plan will be identified according to the perspective of the internal and external stakeholders (parents, teachers, community - local officials, and private individuals). It will validate the efficacy of the implementation of the school's program in adherence to the DepEd's guiding principles and the IATF health protocols.

\section{Research Locale and Sampling}

The study was conducted at Panabo City National High School Panabo City, Davao del Norte. The study respondents were the parents, students, teachers, local officials, and other outside stakeholders nearby the school, which were given a questionnaire to answer or a link for the google form to be answered by the respective respondents.

Quota and purposive random sampling techniques were employed to identify the survey respondents (Creswell, 2017). This includes into consideration the margin of error and degree of significance. It was used to calculate the sample size. Using the statistical tool, actual data will be collected from 100 respondents (35 teachers, 22 students, 25 parents, and 18 local officials and private individuals.

\section{Research Instrument}

A validated researcher-made survey questionnaire on the extent of implementation of the learning continuity plan will be utilized. The survey questionnaire includes the extent of implementation of the protocols followed by the parents, teachers, and external stakeholders in the delivery of students' Learning and the extent of the learning modalities received by students through modular (printed or digital) and online learning or e-learning. The questionnaire was contextualized to the local setting. Refinement of the questionnaire was made possible through the assistance of the adviser and expert panelists for the contents of the questionnaire. For construct validity, the questionnaire was submitted to the validators. Pilot testing was done on random teachers, parents, and outside stakeholders within the Panabo City division to establish the instrument's reliability. The Cronbach Alpha will also be identified to measure the level of reliability.

The questionnaires through printed or google forms were given to the respondents to determine their perceptions about the extent of implementing the learning continuity plan of Panabo City National High School. The Likert scale below was used to calibrate the ratings of the respondents.
$0-0.9-$ not observed and implemented

$1.0-1.5$ - fairly observed and implemented

$1.6-2.5$ - seldom observed and implemented

$2.6-3.5$ - moderately observed and implemented

3.6 - 4.0 - always observed and well implemented

\section{Data Gathering Procedure}

The following steps were undertaken in the gathering of data for this study:

Asking Permission to conduct the study. The researcher wrote a letter addressed to the office of the Schools Division Superintendent through the office of the Secondary School principal to allow the researcher to conduct the study. A letter was also sent to respective respondents asking permission to survey them.

Administration and Retrieval of Questionnaires. After the survey questionnaires were administered to the study respondents, the gathered data were tallied, analyzed, and subjected to statistical analysis by the designated statistician.

Gathering and Tabulation of Data. The collection of data started with the giving of survey questionnaires to the parents, teacher, and other outside stakeholders for their response on the extent of the implementation of the Learning Continuity Plan of Panabo City National High School, mainly on the implementation of the IATF health protocols, the reproduction, distribution, and retrieval of the modules, providing internet access to teachers in their online class in the designated virtual classrooms, providing seminars and trainings to teachers in the new regular strategies of learning process, and assessing the learners in the modular distance learning (MDL) modality and online distance learning (ODL).

After the administration of the test, the results were gathered and were subjected to statistical analysis following Analysis of Variance or ANOVA

Interpretation and Drawing of Implications. Hypotheses were tested at a 0.05 level of significance.

\section{Data Analysis}

Raw data will be consolidated in excel data format with the assistance of an expert statistician. To answer objective in the extent of implementation of learning continuity plan of Panabo City National High School Analysis of Variance (ANOVA) will be employed to explore any significant difference on the level of the implementation of learning continuity plan when analyzed according to profile. 


\section{RESULTS AND DISCUSSION}

Table 1 shows the means (average) rating of the respondents on each indicator.

\begin{tabular}{|c|c|c|c|c|c|c|}
\hline $\begin{array}{l}\text { Respon } \\
\text { dents }\end{array}$ & $\begin{array}{l}\text { Implemen } \\
\text { tation of } \\
\text { the health } \\
\text { protocol }\end{array}$ & $\begin{array}{l}\text { Distribu } \\
\text { tion and } \\
\text { retrieva } \\
1 \text { of } \\
\text { SLM's }\end{array}$ & $\begin{array}{l}\text { Teach } \\
\text { ers' } \\
\text { Capaci } \\
\text { ty and } \\
\text { Capabi } \\
\text { lity in } \\
\text { the } \\
\text { Delive } \\
\text { ry of } \\
\text { Task } \\
\end{array}$ & $\begin{array}{c}\text { Utiliza } \\
\text { tion of } \\
\text { School } \\
\text { Resour } \\
\text { ces }\end{array}$ & $\begin{array}{c}\text { Informati } \\
\text { on } \\
\text { Dissemin } \\
\text { ation } \\
\text { (Online } \\
\text { or } \\
\text { Offline) }\end{array}$ & $\begin{array}{c}\text { Stude } \\
\text { nt }- \\
\text { Teach } \\
\text { er } \\
\text { Learn } \\
\text { ing } \\
\text { Proce } \\
\text { ss }\end{array}$ \\
\hline parents & 3.90 & 3.96 & 3.80 & 3.86 & 3.76 & 3.80 \\
\hline students & 3.90 & 3.80 & 3.80 & 3.90 & 3.90 & 3.80 \\
\hline teachers & 3.86 & 3.80 & 3.69 & 3.69 & 3.74 & 3.71 \\
\hline $\begin{array}{l}\text { other } \\
\text { stakehol } \\
\text { ders }\end{array}$ & 3.72 & 3.67 & 3.75 & 3.61 & 3.67 & 3.75 \\
\hline
\end{tabular}

Anova: Two-Factor Without Replication

\begin{tabular}{|c|c|c|c|c|c|c|}
\hline SUMMARY & Count & Sum & Average & Variance & & \\
\hline parents & 6 & 23.08 & 3.85 & 0.01 & & \\
\hline students & 6 & 23.10 & 3.85 & 0.00 & & \\
\hline teachers & 6 & 22.49 & 3.75 & 0.00 & & \\
\hline other stakeholders & 6 & 22.17 & 3.69 & 0.00 & & \\
\hline Implementation of the health protocol & 4 & 15.38 & 3.84 & 0.01 & & \\
\hline Distribution and retrieval of SLM's & 4 & 15.23 & 3.81 & 0.01 & & \\
\hline $\begin{array}{l}\text { Teachers' Capacity and Capability in the } \\
\text { Delivery of Task }\end{array}$ & 4 & 15.04 & 3.76 & 0.00 & & \\
\hline Utilization of School Resources & 4 & 15.06 & 3.76 & 0.02 & & \\
\hline Information Dissemination (Online or Offline & 4 & 15.07 & 3.77 & 0.01 & & \\
\hline Student - Teacher Learning Process & 4 & 15.06 & 3.77 & 0.00 & & \\
\hline \multicolumn{7}{|l|}{ ANOVA } \\
\hline Source of Variation & SS & $d f$ & MS & $F$ & $P$-value & Fcrit \\
\hline Respondents & 0.105493 & 3 & 0.035164 & 8.998936 & 0.001188 & 3.287382 \\
\hline Indicators & 0.023249 & 5 & 0.004650 & 1.189959 & 0.360075 & 2.901295 \\
\hline Error & 0.058614 & 15 & 0.003908 & & & \\
\hline Total & 0.187356 & 23 & & & & \\
\hline
\end{tabular}

Figure 1. Data Analysis Using ANOVA Two-Way Factor in Excel

It could be seen from the data that the extent of the implementation of the Learning Continuity Plan of Panabo City National High School based on the perception of the parents, students, teachers, and other outside stakeholders were high meaning always observed and well implemented. From the survey, the extent of the implementation of the Learning Continuity Plan of Panabo City National High School in terms of the implementation of the IATF health protocols, the reproduction, distribution, and retrieval of the modules, providing internet access to teachers in their online class in the designated virtual classrooms, providing seminars and trainings to teachers in the new regular strategies of learning process, and assistance of learners in the modular distance learning (MDL) modality and online distance learning (ODL) was given high importance.

\section{CONCLUSION}

There is no substitute for a well-planned activity. In the Department of Education Order No. 12 Series of 2020, ordered the implementation of a BE- LCP in which schools are given guidelines on what to implement for the School Year 2020-2021 during the Covid - 19 where face to face engagement is not permitted because of the threat of the virus. The Learning Continuity Plan was unique to its school since it depends on the availability of funds and resources of the school, response of parents and students of the learning modality to use, teaching force capacity, and capability in carrying out the teaching-learning process of the modalities used by the school, and outside stakeholders and private individuals' support in the implementation of the LCP.

Based on the results, Panabo City National High School, though there are low scores, overall, the school implemented its Learning Continuity Plan very well.

\section{ACKNOWLEDGEMENT}

I, Theresa R. Baman, would like to offer my deepest thanks to the persons listed below who made significant contributions to finish . Dr. Ronald Decano, research adviser and Dean of the Graduate School at Davao del Norte State College, for his encouragement in finishing this work. The panel examiners provided constructive comments and recommendations that considerably assisted in the quality of this work. Prof. Mark Van M. Buladaco and Gel Marie Buladaco for assisting with the completion and submission of this paper for publication. Mam Memia B. Infiesto, our school's administrator, encouraged me to step beyond my comfort zone. To Dr. John Visillas and Rex F. Cañete, who supported me in crafting and validating the questionnaire.

In addition, I would like to thank my husband, Fernando D. Baman Jr., and our children for their inspiration and support. Thank you to my family, friends, students, and respondents who helped me complete this work in a timely manner. Finally, and most significantly, I want to thank God, our beloved almighty father, for the direction and power that has enabled us to achieve this noble goal.

\section{REFERENCES}

[1] Bernardo, J. (2020, July 30). Modular Learning most preferred parents: DepEd. ABS-CBN News.https://news.abscbn.com/news/07/30/20/modular-learning-most-preferred-byparentsdeped

[2] FlipScience. (2020, October 5). 'Tagapagdaloy': How Filipino parents can help ensure successful modular distance learning. FlipScience - Top Philippine Science News and Features for the Inquisitive Filipino. https://www.flipscience.ph/news/featuresnews/tagapagdaloymodular-distance-learning/

[3] The University of Saskatchewan, Pandemic Influenza Preparedness Planning, Unit Planning Guide and Workbook,Feb (2006) Sarah Gonser Tips for Principals Shifting Their Schools to Distance Learning. March 25, 2020

[4] Quinones, M. T. (2020, July 3). DepEd clarifies blended, distance learning modalities for SY 20202021. Philippine Information Agency. https://pia.gov.ph/news/articles/1046619

[5] Tria, J. Z. (2020, June 3). The COVID-19 Pandemic through the Lens of Education in the Philippines: $\quad$ The New Normal. 
International Journal of Research and Innovation in Social Science (IJRISS) |Volume V, Issue XI, November 2021||ISSN 2454-6186

ResearchGate.

https://www.researchgate.net/publication/341981898_The_COVI D-

19_Pandemic_through_the_Lens_of_Education_in_the_Philippine s_The_New_Normal
[6] Llego, MA. (n.d). DepEd Learning Delivery Modalities for School Year 2020-2021. TeacherPh. https://www.teacherph.com/deped-learning-delivery-modalities/ 